\title{
The Evaluation Model of Integrated Social Sciences Learning Program
}

\author{
Nana Suraiya $^{1, *}$, Yusrizal $^{2}$, M Shabri Abd. Majid $^{3}$, Deny Setiawan ${ }^{4}$ \\ ${ }^{1}$ Doctoral Program in Social Studies Education of Syiah Kuala University, Banda Aceh, Indonesia \\ ${ }^{2}$ Faculty of Education and Teacher Training of Syiah Kuala University, Banda Aceh, Indonesia \\ ${ }^{3}$ Faculty of Economics and Business of Syiah Kuala University, Banda Aceh, Indonesia \\ ${ }^{4}$ Faculty of Social Science, University of Medan, Indonesia
}

Received July 4, 2020; Revised September 12, 2020; Accepted September 29, 2020

\section{Cite This Paper in the following Citation Styles}

(a): [1] Nana Suraiya, Yusrizal, M Shabri Abd. Majid, Deny Setiawan, "The Evaluation Model of Integrated Social Sciences Learning Program," Universal Journal of Educational Research, Vol. 8, No. 11B, pp. 5779 - 5789, 2020. DOI: 10.13189/ujer.2020.082212.

(b): Nana Suraiya, Yusrizal, M Shabri Abd. Majid, Deny Setiawan (2020). The Evaluation Model of Integrated Social Sciences Learning Program. Universal Journal of Educational Research, 8(11B), 5779 - 5789. DOI: 10.13189/ujer.2020.082212.

Copyright $\bigcirc 2020$ by authors, all rights reserved. Authors agree that this article remains permanently open access under the terms of the Creative Commons Attribution License 4.0 International License

\begin{abstract}
This study aims to produce an evaluation model of the Integrated Social Sciences learning program in junior high schools. The subject of social studies education plays an important aspect in school, because it is not only teaching knowledge, but also it educates character for the students. However, generally there is no clear guideline on how the evaluation of the students undertaken by the teachers works. Since there are a wide range of evaluation models by the scientist, this study will focus on the use of Borg and Gall models. A qualitative method was used with Research and Development (R\&D) approach which consists of ten stages. The data collection technique used was simple random sampling with a total of 350 students from eight schools in Aceh Province. It used questionnaires, tests and documentation. The instrument validity includes face validity and content validity. It is also analyzed by expert judgment. Furthermore, construct validation was analyzed by confirmatory factor analysis (CFA). The instrument reliability estimation uses the Cronbach Alpha formula with the help of the SPSS for Window 16.0 program. The results of the evaluation model research produced are called EP_PISTdu. It is an evaluation model that can be undertaken by social studies education teacher to measure student's ability. After the model was examined towards some school, it can be concluded that the EP_PISTdu evaluation model product is feasible to be used as a system to measure the Evaluation of Integrated Social Studies Learning Programs in junior high
\end{abstract}

schools. The EPISTdu can be used by the teachers, especially in social studies education module in junior high school level.

Keywords Social Sciences Evaluation Model, Program Evaluation, Learning Model

\section{Introduction}

Junior High School (SMP) is one of the basic educational institutions in the National Education System. Therefore, SMP must implement the provisions in national education standards. These provisions have been regulated in the law, one of which is in Article 35 Paragraph 1 of Law Number 20 Year 2003 concerning the National Education System, which regulates: content standards, processes, graduate competencies, education personnel, infrastructure, management, education funding and assessment (Komarudin, Alkhudri, Ubedilah, Syaifudin, \& Casmana, 2019).

An important factor for improving the quality of education can also be through programs in schools, one of the programs at the junior secondary level is an integrated Social Sciences (IPS) program. The purpose of Integrated Social Studies learning in junior high school education units is so that students have the ability (1) to recognize 
concepts related to community life and the environment. Having the basic ability to think logically and critically, curiosity, inquiry, problem solving and skills in social life. (2) has a commitment and awareness of social and human values. (3) have the ability to communicate, cooperate, and compete in a pluralistic society at the local, national and global levels (Sarkadi, Casmana, \& Rahmawati, 2020).

In its development, social studies education in Indonesia faces many basic problems, one of which is an internal problem. Cholisin (2006) explained that the most fundamental internal problem in social studies learning is the problem of the concept and meaningfulness of social studies education yet to be realized. The concept of social studies as a subject in schools consists of various branches of social science cannot yet be said to be integrated because each of the social sciences that will be taken as part of social studies subjects cannot yet be determined which social science is a priority, therefore ideas and concepts Social studies as a school subject has not been realized as a whole in a single unit. Its implementation in social studies learning schools is still largely implemented separately. Achievement of core competencies and basic competencies of social studies subjects are still carried out in accordance with their respective fields of expertise without any integration therein. This certainly hinders the achievement of the IPS objectives themselves which are formulated as the basis of reality and social phenomena that embody an interdisciplinary approach from aspects and branches of social science (sociology, history, geography, politics, law and culture) (Sumadi \& Casmana, 2020).

The quality of education is also influenced by several factors including teachers, research conducted by Fadia Nasser and Abu Alhija (2016), showing that good teacher competence will affect good learning outcomes. Teacher competency assessment is obtained through students' perceptions / perspectives on their teacher in the learning process in class. Likewise, the research conducted by Andria Muntaner (2016) with the results of the study showed that with structural analysis of equation modeling (SEM) teacher teaching skills, student emotions affect students' academic abilities. Similar results were also shown by research conducted by Evelien (2017) that there is a relationship between teacher performance goals and student achievement (Zid, Casmana, \& Hijrawadi, 2020). It also includes student learning motivation in determining a future successful student (Maximiliane, 2017; Bear, 2017).

Then the factor of the infrastructure of learning infrastructure Ellis (1998: 12) states that social studies learning will run effectively if supported by a conducive environment. Research conducted by Joseph Han and Keunkwan Ryu (2015) shows that the physical environment of the classroom or learning infrastructure has a significant influence on student learning and teacher performance. Classrooms that are uncomfortable, hot, cold and many who are passing by are obstacles to achieving better learning. Teachers to be able to teach well require calmness, security, comfort, adequate lighting and freedom from crowd disturbances (Claude Fernet: 2015). Also, there are a wide range of researchers who argue that social studies learning process can affect students' achievement in pursuing their success.

According to Cruickshank in Widoyoko (2013), learning infrastructure that affects the quality of the learning process is class size, class size, air temperature, light, sound, and learning media. Whereas John Jongho Park (2017) states that one of the learning facilities that support the learning process is a laboratory, laboratory infrastructure facilitates teachers and students to experiment about learning material (Zid, Casmana, \& Hijrawadi, 2020; Widioko, 2013; Zid, Alkhudri, Casmana, Marini, \& Wahyudi, 2020; Sumadi \& Casmana, 2020; Dennis fung, 2016).

Field observations, also in every school, do not yet have complete integrated social infrastructure program facilities, no schools have specialized social studies programs, there are no special media and tools that support social studies learning, therefore integrated social learning is verbal. This also impacts on the enthusiasm and motivation of student learning. The results of talks with several students, they say that integrated social studies learning is difficult to understand and like imaginary lessons (Sarkadi \& Casmana, 2020; Suhadi, Syafrudin, \& Casmana, 2020).

One of the goals of program evaluation is to produce information that can be used as a basis for decision making, policy formulation, and subsequent programming. For information to function optimally, information generated from program evaluations must be complete, valid and reliable and timely in delivery. Evaluation in the field of education in terms of its objectives can be divided into two, namely evaluations that are macro and micro. Macro evaluation targets the education program in general, which are a program planned to improve the field of education; micro-evaluation is often used at the classroom level. Therefore, the target of micro evaluation is learning in the classroom (Djemari Mardapi 2000: 2)

Thus, evaluation is not only focused on the assessment of learning outcomes, but also needs to be based on an assessment of the input and process of the program itself. In this conception, the optimization of the evaluation system has two meanings, namely the evaluation system that provides optimal information, and the benefits achieved from the evaluation Djemari Mardapi (2003: 12). The main benefit of conducting an educational evaluation is to improve the quality of the program.

Research on the development of the IPS evaluation model has been conducted by Sugeng Eko P. Widiyoko (2013), who developed the EKOP model, which is an evaluation model of the quality and output of social studies learning. The learning quality components include: teacher quality, student motivation and attitudes, learning infrastructure and learning climate, while the output component includes academic skills, social skills and personal skills. This model was developed as a 
combination of the CIPP evaluation model (context, input, process, product) of Stufflebeam and Kirkpatrick (Sarkadi, Casmana, \& Rahmawati, 2020). The results of the development of the recommended EKOP model can be used as an alternative for school leaders to evaluate social studies learning programs in junior high schools.

Based on the description above, the researcher wants to develop also a more comprehensive evaluation model that can cover all components. The model to be developed is an evaluation model of an integrated social studies learning program which includes: (1) evaluation of inputs including components: teacher competency, student motivation, learning infrastructure. (2) evaluation of the process, namely the implementation of learning in class (3) evaluation of the product, namely the results of integrated social studies learning which includes: competency hood, knowledge competency and skills competency. The existence of this model is expected to provide accurate and complete information about integrated social studies learning programs in junior high schools.

\section{Methods}

This type of research is research and development (R\&D), using the Borg \& Gall model (1983, p. 775) consisting of 10 steps. The steps of the Borg \& Gall model development research were then simplified into three steps, namely: (1) the pre-development stage of the model, (2) the stage of developing the model, and (3) the stage of field operations (testing the model). The results of this simplification are then compiled into a chart of development procedures that can be seen in the figure. The following 3:

The evaluation model instrument that was piloted consisted of instruments to measure inputs, processes and outputs. Trials are carried out to see the content validity, construct validity, reliability and the suitability of the measurement model, namely the fit between the theoretical concept model and empirical data.

\section{Validity and reliability test}

Before being tested, the prototype is validated in advance by experts (expert judgment). Trial procedures, instruments and evaluation guides are carried out with Delphi techniques through expert judgment (expert judgment). The Delphi technique is an interactive and systematic forecasting based on individual feedback and selected values of one or more rounds. Evidence of the validity of the contents of the test or instrument is carried out by a panel of experts according to the field being measured and the expert in the field of measurement (Mardapi. 2012: 17-19). The extent to which the contents of these items represent the components in the overall object to be measured or the extent to which items reflect the behavior to be measured (Azwar, 2010: 52). Validation by experts (expert judgment) is done by: 1). evaluation expert, 2). expert research methodology, 3). social studies education expert, 4 social studies subject teachers. This validation is carried out by circulating the initial draft of the instrument using a Likert scale with the answer choices very suitable, suitable, quite suitable, less suitable, and not suitable. In addition to using these answer choices, experts are also asked for proposals, suggestions, and opinions on the proposal sheet. suggestions and opinions.

The next step is to conduct a limited trial of the instrument. The limited testing was carried out in eight junior high schools in the cities of Banda Aceh and Aceh Besar, namely in SMP Negeri 1, SMP Negeri 8, SMP Negeri 13, and SMP Negeri 18 Kota Banda Aceh. While the parties involved in this second trial were: 4 school principals, social studies teachers, 115 class IX students.

The expanded trial (implementation) was carried out in 18 junior high schools in the Province of Aceh, given the vast geographical area of the Aceh Region, the determination of the test subjects was determined by dividing the zones of regional zones.

The results of Delphi test can be seen from the table below.

Table 1 shows the evaluation of the evaluation model guide conducted by experts and users (school principals and social studies teachers), all components of the evaluation guide showed an average score of 4.69 , which means that all components of the evaluation guide were classified as very good.

Table 1. The results of validation by experts on the Integrated Social Studies Learning Program Evaluation Model Guide

\begin{tabular}{|c|c|c|c|c|c|c|c|c|c|c|}
\hline No & Rated aspect & V1 & $\mathrm{V} 2$ & V3 & V4 & V5 & V6 & V7 & V8 & Average \\
\hline 1 & Clarity of content of general evaluation instructions & 4 & 4 & 5 & 5 & 4 & 5 & 5 & 4 & 4,50 \\
\hline 2 & Clarity of the steps of the assessment process & 5 & 4 & 5 & 5 & 5 & 5 & 5 & 5 & 4,87 \\
\hline 3 & Clarity of time for evaluation & 4 & 4 & 4 & 5 & 5 & 5 & 5 & 5 & 4,62 \\
\hline 4 & Clarity of how the score is processed & 4 & 5 & 5 & 5 & 5 & 5 & 4 & 4 & 4,62 \\
\hline 5 & Completeness of the contents of the guide & 5 & 5 & 5 & 5 & 5 & 4 & 5 & 5 & 4,87 \\
\hline 6 & The effectiveness of standard sentences / sentences & 4 & 4 & 4 & 5 & 5 & 5 & 5 & 5 & 4,62 \\
\hline 7 & The use of words and terms is easy to understand & 4 & 4 & 5 & 5 & 5 & 5 & 4 & 4 & 4,50 \\
\hline 8 & Accuracy of spelling and punctuation & 5 & 4 & 5 & 5 & 5 & 5 & 5 & 5 & 4,87 \\
\hline \multirow[t]{2}{*}{9} & Font shape and size & 5 & 4 & 5 & 5 & 5 & 5 & 4 & 5 & 4,75 \\
\hline & Average & & & & & & & & & 4,69 \\
\hline
\end{tabular}




\section{Data Collection and Data Analysis}

Data collection in this study was carried out by interview, observation, questionnaire (questionnaire) and documentation. To get a glimpse of the research data therefore it is easier to read and meaningful, descriptive analysis is used.

Qualitative data analysis is intended to analyze the results of validation (assessment) data by experts (expert judgment) who provide input in order to improve evaluation procedures, evaluation guides, instruments and data about the effectiveness of the developed model. Then based on the score given by the experts on these components, the average score is collected and converted to 5 scales which are then described. The usefulness of the results of the description is the basis for determining whether the procedures, instruments and evaluation guidelines that have been developed are qualified as good models. The results of the description are also used to see the effectiveness of the model.

Descriptive analysis is also carried out on the results of the implementation data (expanded test) to see the quality of the implementation of integrated social studies learning programs in the SMP Negeri Aceh Province.

\section{Results and Discussion}

The Integrated IPS Learning Program Evaluation Study resulted in an evaluation model of the Integrated IPS learning program for junior high school level and the implementation of the evaluation model at the junior high school level, namely for the input components were categorized as good, the process components were categorized as very good and the product components were categorized as very good. Overall, the Integrated IPS learning program at the junior high school level in Aceh Province is categorized as very good.

The names of the themes being tested or aspects of the aspects contained in the test questions, namely: a, Diversity of Earth Forms, Geosphere and Population Symptoms, b) Development of Cultural Societies and Government from Pre-Literacy to Maintaining the Unitary State of the Republic of Indonesia, and c, Indonesian Economic Activities, International Economic Cooperation and Institutions

\section{Development of an Evaluation Model for Integrated Social Studies Learning Programs}

Before conducting an evaluation of the implementation of an integrated social study learning program, the evaluation model of the integrated social studies learning program is developed the development of the evaluation model follows Borg and Gall which are then divided into three major stages, namely: the pre-development stage, the stage of development and testing of the model.

\section{Pre-development Stage}

Development of evaluation models begins with the activity of studying theories, reviewing previous studies that have been done before, gathering detailed information and gathering a number of problems found in research in the field (Creswell, 2009: 97). The theoretical study and relevant research results are intended to find solutions to the main problems of integrated social studies learning programs, namely the absence of a comprehensive and integrated evaluation model at the junior secondary level.

Then conduct a survey to school so that it can be seen the implementation of integrated social studies learning programs in schools and to get information about evaluating integrated social studies learning programs in schools. Information is obtained through direct observation, documentation and interviews with teachers and students. The initial survey was conducted in January 2016, by coming directly to the school to see the teacher's competence in the teaching and learning process, student enthusiasm in learning, the condition of school facilities and infrastructure as well as seeing the evaluation process carried out by the teacher. The results (output) of integrated social studies learning were also examined through document review, namely the report cards and USBN grades of the previous year. Then they also conducted interviews with several teachers and students about the integrated social studies learning program. Information about integrated social studies learning is also found by researchers directly on the implementation of training programs and the teaching profession (PLPG). From the results of interviews and teacher observations found about the implementation of integrated social studies learning in schools, the constraints faced by teachers and the ability of teachers to develop integrated social studies learning plans. The teacher also provides information about student perceptions and motivation to learn integrated social studies subjects in schools.

The initial data results obtained from the initial survey stage are that the researcher knows a) the implementation of integrated social studies learning, 2) the components that influence integrated social studies learning, 3) the types of evaluations that have been carried out by the teacher and the teacher's perceptions about integrated social studies and 4 ) Integrated social studies learning evaluation model. The findings in this stage are used to determine the steps needed as a basis for product development and evaluation focus.

After conducting the survey, the researcher also reviewed based on previous studies which together developed evaluation models in the field of education. Based on previous researchers namely Bin and Qing (2008) applying the CIPP-based educational evaluation model, where the model is developed from aspects of teaching objectives, teaching resources, teaching schemes and teaching outcomes. Similar to Neyati, Arab, Freshteh Farzianpour and Majdabadi (2016) initially explained that educational evaluation was able to improve academic 
quality related information which greatly contributed to accountability among authorities and influenced Academic ranking. In his research among many evaluation models, the CIPP or Context, Input, Process model, where the product model is a very useful and recommended method for educational evaluation

Continued results of the preliminary survey found that there is no evaluation model of integrated social studies learning programs in a comprehensive and comprehensive manner, therefore it is necessary to design an evaluation model that can provide an overview and information about the implementation of Integrated Social Studies learning programs at the SMP level. Evaluations conducted by schools only include components of learning outcomes, namely through tests to measure students' knowledge competencies, and affective competencies and skills competencies are only carried out in the teaching and learning process through observation sheets. Evaluation of learning outcomes for affective competencies and skills competencies can be done through self-assessment. Then the evaluation of inputs and the learning process which are the two major components in the learning program have not been evaluated. Therefore, the model developed is called the evaluation model of an integrated social studies learning program consisting of three components, namely: evaluation of input, process evaluation and product evaluation. The integrated social studies learning program evaluation model is equipped with evaluation procedures, instruments and evaluation guides. This study will adopt three components of the CIPP model, namely: input evaluation, process evaluation and product evaluation from Stufflebeam.

\section{Product Development Stage}

After the pre-development stage is carried out, then a prototype is designed. The initial stage in developing this evaluation model is to first design the product components, product assessment sheets and instruments in the form of a questionnaire as a program evaluation tool that will be integrated in the model. In designing the initial product components of the evaluation model in the form of a questionnaire, the researcher developed an instrument grid based on the evaluation objectives to be carried out as well as considering evaluation tools. The evaluation model of the integrated social studies learning program consists of three components of the CIPP, namely input evaluation, process evaluation and product evaluation, then evaluation procedures, evaluation instruments and model use guidelines are compiled.

Validation by experts (expert judgment) is done by: 1). evaluation expert, 2). expert research methodology, 3). social studies education expert, 4). Social studies teacher. This validation is carried out by circulating the initial draft of the instrument using a Likert scale with the answer choices very suitable, suitable, quite suitable, less suitable, and not suitable. In addition to using these answer choices, experts are also asked for proposals, suggestions, and opinions on the proposal sheet. suggestions and opinions. The results of the expert assessment will then be improved, then re-consulted with the supervisor. Aspect of evaluation guide evaluation focused on aspects regarding the contents of the guide and the language used. Evaluation of the contents of the evaluation guide includes: (1) clarity of general guidelines, (2) clarity of evaluation steps, (3) clarity of steps and purpose of the evaluation results and (4) clarity of evaluation time (5) clarity of how to score, and (6) completeness of the contents of the guide. As for the assessment of aspects of language include: (1) the effectiveness / stiffness of sentences (2) the use of sentences and words that are easily understood by users of the evaluation model, (3) the accuracy of spelling and punctuation, (4) the size and shape of letters.

Furthermore, the results of validation by experts and users can be seen in the following table:

Table 2. Results of validation by experts of the Integrated Social Learning Program Evaluation Model Guide

\begin{tabular}{ccccccccccc}
\hline No & Rated aspect & $\mathrm{V} 1$ & $\mathrm{~V} 2$ & $\mathrm{~V} 3$ & $\mathrm{~V} 4$ & $\mathrm{~V} 5$ & $\mathrm{~V} 6$ & $\mathrm{~V} 7$ & $\mathrm{~V} 8$ & Avr \\
\hline 1 & Clarity of contents of general evaluation instructions & 4 & 4 & 5 & 5 & 4 & 5 & 5 & 4 & 4,50 \\
\hline 2 & Clarity of the steps of the assessment process & 5 & 4 & 5 & 5 & 5 & 5 & 5 & 5 & 4,87 \\
\hline 3 & Clarity of evaluation time & 4 & 4 & 4 & 5 & 5 & 5 & 5 & 5 & 4,62 \\
\hline 4 & Clarity of how to score & 4 & 5 & 5 & 5 & 5 & 5 & 4 & 4 & 4,62 \\
\hline 5 & Complete contents of the guide & 5 & 5 & 5 & 5 & 5 & 4 & 5 & 5 & 4,87 \\
\hline 6 & Effectiveness of sentences / standard sentences & 4 & 4 & 4 & 5 & 5 & 5 & 5 & 5 & 4,62 \\
\hline 7 & The use of words and terms is easy to understand & 4 & 4 & 5 & 5 & 5 & 5 & 4 & 4 & 4,50 \\
\hline 8 & accuracy of spelling and punctuation & 5 & 4 & 5 & 5 & 5 & 5 & 5 & 5 & 4,87 \\
\hline 9 & font shape and size & 5 & 4 & 5 & 5 & 5 & 5 & 4 & 5 & 4,75 \\
\hline & & Average & & & & & & & 4,69 \\
\hline
\end{tabular}

Information: V: Validator 
Table 1 about the EP_PISTdu evaluation guide model evaluation carried out by experts and users (IPS teachers). First, it is seen from the aspect of clarity of the contents of the general evaluation instructions, averaged 4.50 with very good classification. This explains that the clarity of the contents of the evaluation model instructions is very easy to understand and understand for each component. Second, the clarity of the assessment process steps is 4.47 with very good classification. In this model each step in the assessment process has been explained clearly below especially in the use of the rating scale. Third, the clarity of evaluation time was 4.62 with good classification. Basically, the timing of the evaluation is related to the use of this model, which is flexible, in the sense that it can be used any time. But the right time is at the end of the semester. Fourth, the clarity of data processing method is 4.62 with very good classification. This model also includes how to process the scores obtained together with the calculation table, because each user (teacher and principal) is very easy to implement. Fifth, completeness of the contents of the guide obtained an average of 4.87 with very good classification. This module is accompanied by a chapter that will discuss guidelines for using the
EP_PISTdu model, so that users can observe each of the steps in their use. The six effectiveness of the kaliman obtained average of 4.62 and to the use of words and terms easily understood obtained an average of 4.50 with the same classification that is very good. Similarly, the aspects of the darkness, namely the accuracy of spelling and punctuation as well as the shape and size of letters have a very good classification. This explains both in terms of the language the user has been able to read and understand the intent of each instrument so that it does not result in biased perception. Overall, the evaluation guide components EP_PISTdu have been rated very well all components of the evaluation guide.

Based on the results of validation by the user (social studies teacher) and expert (expert) relating to the evaluation model EP_PISTdu classified very well and feasible to proceed with the testing phase of the model. However, before testing the model, as for the suggestions given by the user (social studies teacher) and expert (expert) to do. Basically, not because it is not feasible, but basic additions so that the evaluation model EP_PISTdu is better. The following is a summary overview of the overall model assessment:

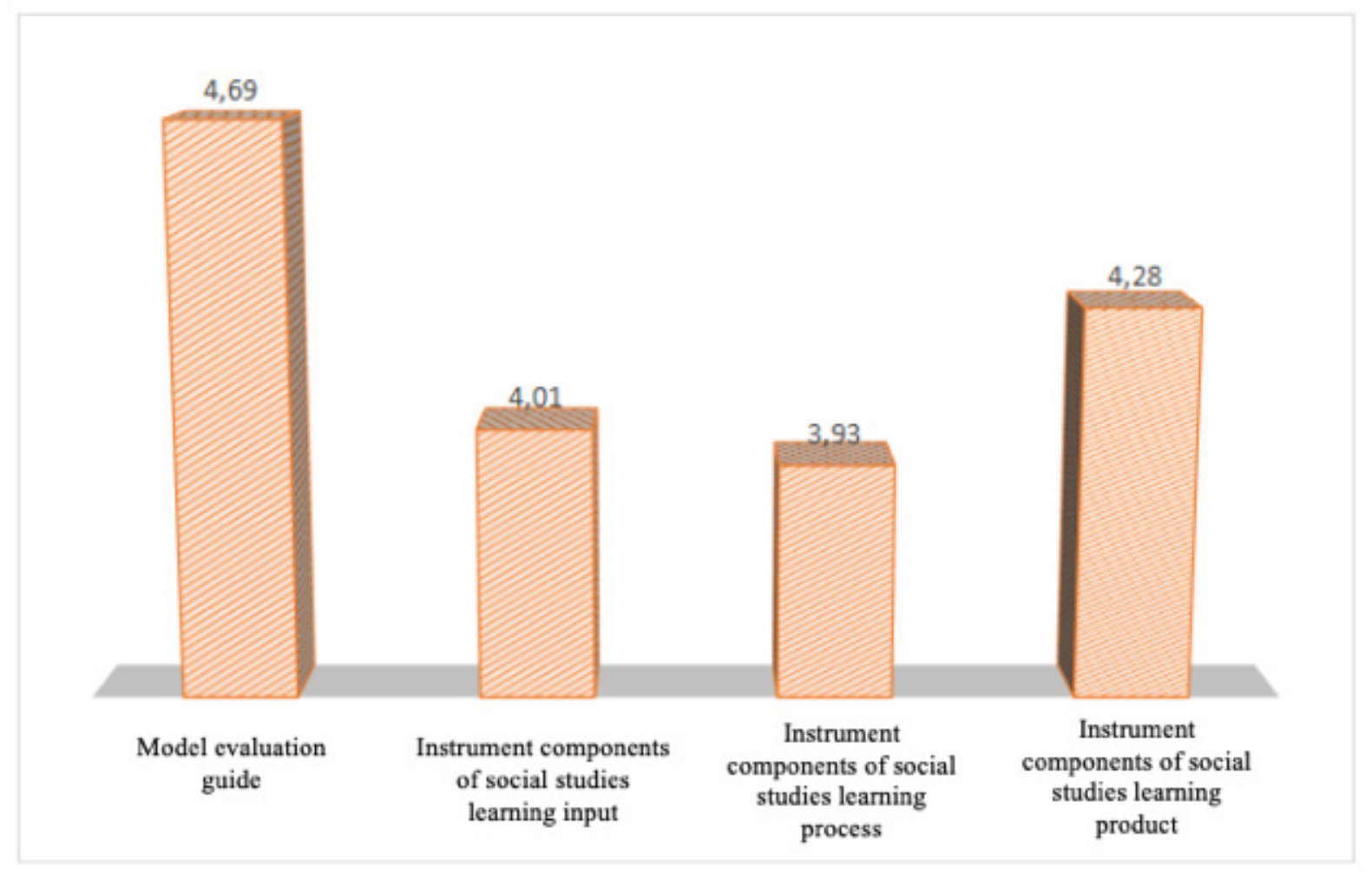

Figure 1. Overall Evaluation Model Evaluation 
From the overall evaluation model evaluation results, it can be seen that the average value of the Evaluation Model Guide of 4.69 is in the very good category Then the Input Components of the IPS Learning Program at 4.01 are in the good category, and the Process Components of the IPS Learning Program at 3.93 are in the good category and the IPS Learning Program Product Component of 4.28 are in the good category too. Overall guidelines and evaluation models of integrated social studies learning programs obtained an average score of 4.22 with the conclusion that the evaluation model was appropriate and feasible.

Furthermore, after the EP_PISTdu evaluation model has been feasible to be field-tested for proof of construction validity or question / statement items in the instrument. Proof of construct validity is carried out to see the question / statement items in each valid and reliable component to measure the effectiveness of the EP_PISTdu evaluation model in the final product.

Basically, the purpose of the expanded trials in this research development is intended to be: 1) trials are carried out to determine the suitability of the model and the accuracy of the evaluation model. 2) to find out whether the evaluation model instruments can be used to evaluate integrated social studies learning programs in junior high schools. In the trial phase, it will be expanded before it is used as an evaluation model, but it will test the suitability of the model and the accuracy of the evaluation model through a CFA (Confirmatory Factor Analysis) analysis. CFA analysis as a measurement model (measurement model). Analysis of the measurement model contains 3 steps namely the model fit test (Overall Model Fit), the loading factor value, and the value of Construct Reliability (CR). The loading factor value of each indicator must have a value of $\geq 0.3$. This study refers to Hair, Black, Babin, Anderson, \& Tatham (2010) which states that "factor loadings \pm 0.3 to 0.4 are minimally acceptable". While the reliability of the measurement model is seen from the value of Construct Reliability (CR), the reliability level of CR $\geq$ 0.60 is acceptable for exploratory research. The stages in the Confirmatory Factor Analysis (CFA) in the study were carried out in 1 phase, namely the CFA separately for each contract (component of the evaluation model).

\section{Confirmatory Factor Analysis (CFA) Input Component}

Before estimating the validity with the loading factor value, the feasibility / suitability of the model must first be tested to be used to test how good the level of goodness of fit of the model. The results of the model analysis after constraints on problem covariance errors, obtained the level of goodness of fit in good enough conditions where the criteria of goodness of fit in conditions of fit and marginal fit (chi-square: 4005,847, P: 0,000; RMSEA: 0,050; CFI: 0.906, GFI: 0.762; IFI: 0.907; NFI: 0.830 and
AGFI: 0.723). According to Solimun (2005), if there are one or more parameters that are fit then the model is declared fit (Semuel, 2007) in his study Aryani and Rosinta (2010). The same is true of the opinions of Yeni, Wahab, Zakaria, and Hanafi, Agustina. (2018) states "From testing the overall suitability of the model, showed the good model was $75 \%$, therefore the SEM model was good". With this result, overall, it can be said that the structural test model is in good condition and further analysis can be done.

Based on the results of the analysis from 3 aspects of the input components namely teacher competency, student motivation and infrastructure of 68 items where each majority obtained loading factor value factor 0.30 (Valid), except for items MS08, MS07 and SP21 because it has loading factor $<0.30$ (Invalid). Hair, Black, Babin, Anderson, \& Tatham (2010) which state that "factor loadings \pm 0.3 to 0.4 are minimally acceptable".

The results of the acquisition value of construct reliability in this study are as follows:

Table 3. Reliability Test Instruments EDD1, EDD2, EDD3

\begin{tabular}{cccc}
\hline Component/Subcomponent & $\lambda_{\mathrm{i}}$ & $\varepsilon_{\mathrm{i}}$ & $\mathrm{CR}$ \\
\hline Teacher competence & 14,064 & 6,029 & 0,970 \\
\hline Student Motivation & 10,643 & 6,499 & 0,946 \\
\hline Infrastructure & 9,699 & 5,801 & 0,942 \\
\hline
\end{tabular}

Table 2 above shows the results of construct reliability values in the study. From the calculation results obtained by sub-components that have Composite reliability $\geq 0.7$, namely the KS dimension (teacher competency), namely CR: 0.970; MS dimension (student motivation), namely CR: 0.946; and the dimensions of the SP (Target Means), namely CR: 0.942 . The above results show that 65 question items of the 3 sub-components used have a high level of reliability and can be stated to be reliable. This shows every valid question / statement item has a fairly high level of reliability, so that it is able to measure respondents' perceptions regarding the effectiveness of teacher competencies, student motivation and infrastructure.

\section{Confirmatory Factor Analysis (CFA) processing component}

Just as proof of validity on the instrument component input is also carried out verification of validity. The first step is to look at the level of goodness of fit of the research model. After re-estimation, the level of goodness of fit is obtained in good condition where criteria of goodness of fit are in fit and marginal fit conditions (chi-square: 259,897; P: 0,000; RMSEA: 0,045; CFI: 0,975; GFI: 0,944; IFI: 0,944; 0,976; NFI: 0,948 and AGFI: 0,900$)$. Following are the results of the process of modification indicate in the process component sub-indicators: 


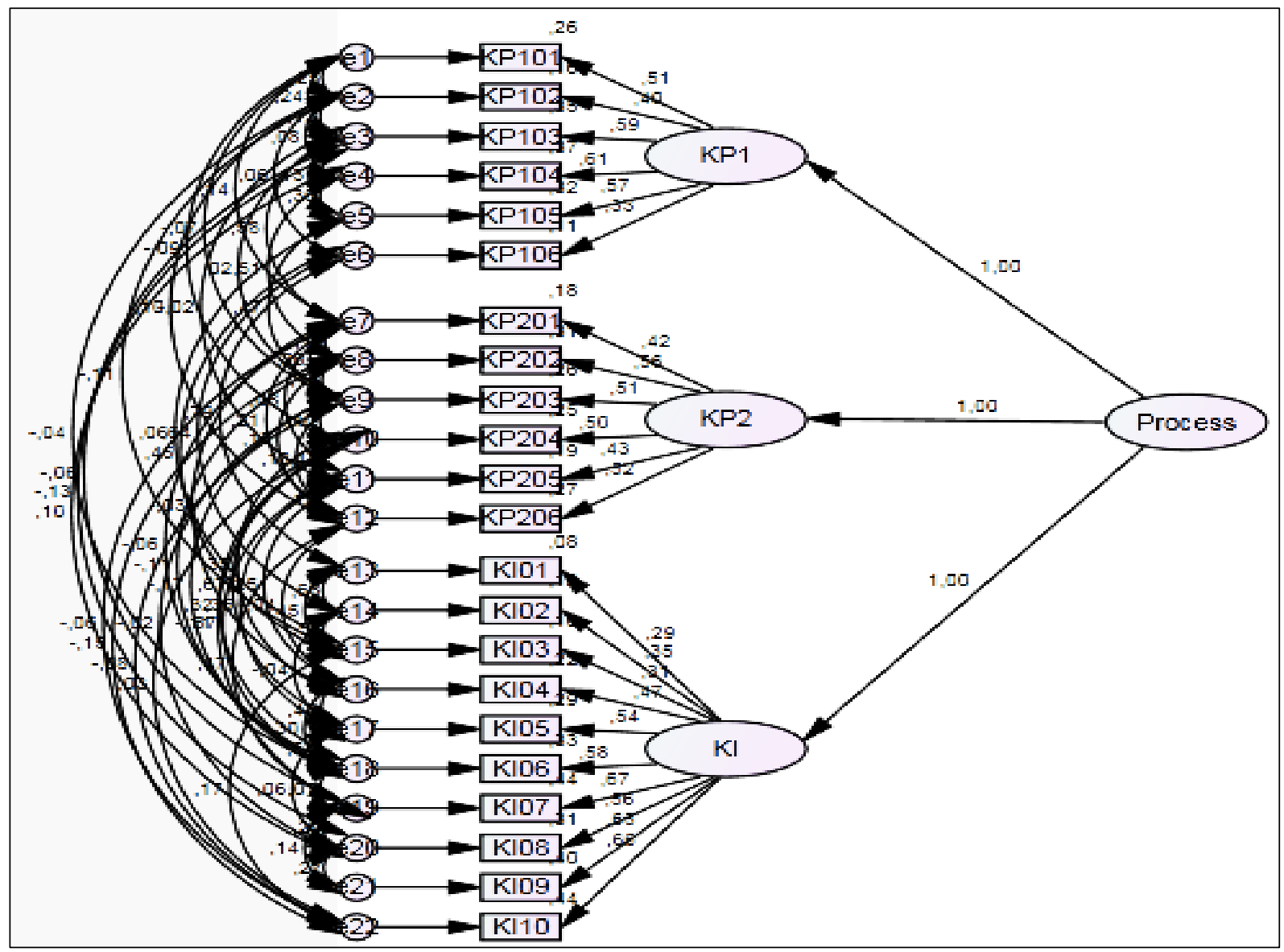

Figure 3. Structural Model of the Process Components sub-indicator

Based on the results of the analysis above shows from 3 aspects of the process components in the learning activities of 22 items where each majority obtained loading factor value $\geq 0.30$ (Valid), except for item KI01 because it has a loading factor $<0.30$ (Invalid).

Next is the reliability estimate. The results of the acquisition value of construct reliability in this study are as follows:

Table 4. Instrument Component Process Reliability

\begin{tabular}{ccccc}
\hline \multicolumn{2}{c}{ Component/Subcomponent } & $\boldsymbol{\lambda}_{\mathbf{i}}$ & $\boldsymbol{\varepsilon}_{\mathbf{i}}$ & $\mathbf{C R}$ \\
\hline \multirow{2}{*}{$\begin{array}{c}\text { Learning } \\
\text { process }\end{array}$} & $\begin{array}{c}\text { Preliminary } \\
\text { activities }\end{array}$ & 3,003 & 1,786 & 0,835 \\
\cline { 2 - 5 } & Core activities & 2,943 & 1,624 & 0,842 \\
\cline { 2 - 5 } & Closing Activity & 4,777 & 2,719 & 0,894 \\
\hline
\end{tabular}

Table 3 above explains the results of the value of construct reliability obtained from the calculation results obtained variables that have Composite reliability $\geq 0.7$, namely the preliminary activities (KP1) CR value: 0.835 ; dimension of core activities (KI) CR value: 0.894; dimension of closing activity (KP2) CR value: 0.842 . This shows that 21 items from 3 sub-components used have a high level of reliability and can be declared to be reliable. It can be interpreted that each statement item from two sub-components has a relative or reliable character to measure the process of learning activities.

\section{Confirmatory Factor Analysis (CFA) Product component (output)}

First look at the level of goodness of fit of the research model. After re-estimation, the level of goodness of fit is obtained in good enough condition where criteria of goodness of fit in marginal fit (chi-square: 7253,478; P: 0,000; RMSEA: 0.042; CFI: 0.823, GFI: 0.724; IFI: 0.724; 0.826; NFI: 0.661 and AGFI: 0.724).

Based on the results of the analysis, it can be seen from 3 aspects of the process components in the learning activities of 96 of the 3 dimensions where each loading factor value obtained $\geq 0.30$ (Valid), except KS208, KP9, KP11, KP12, KP13, KP14, KP20, KP32, KP32, KP33, KP35 and KP37. Thus, it can be concluded that 82 items have a good level of validity for the measurement of product components seen from the attitude, knowledge and skills competency and can be used for further analysis.

Next is the reliability estimate. The results of the acquisition value of construct reliability in this study are as follows: 
Tabel 5. Reliabilitas Instrumen Komponen Proses

\begin{tabular}{ccccc}
\hline \multicolumn{2}{c}{ Component/Subcomponent } & $\boldsymbol{\lambda}_{\mathbf{i}}$ & $\boldsymbol{\varepsilon}_{\mathbf{i}}$ & $\mathbf{C R}$ \\
\hline \multirow{2}{*}{$\begin{array}{c}\text { Output } \\
\text { component }\end{array}$} & $\begin{array}{c}\text { Attitude } \\
\text { Competencies }\end{array}$ & 14,582 & 10,365 & 0,954 \\
\cline { 2 - 5 } & Knowledge & 14,132 & 3,874 & 0,981 \\
\cline { 2 - 5 } & Skills & 13,317 & 6,636 & 0,964 \\
\hline
\end{tabular}

Table 4 above explains the results of construct reliability values obtained. The value of each variable obtained by construct reliability values is greater or equal to 0.70 . Dimension of attitude competency (KS2) CR value: 0.954 ; dimension of knowledge competence (KP) CR value: 0.981; Skills competency dimension (KK) CR value: 0.964 This shows that the items have excellent reliability values and are able to measure the dimensions and latent constructs for the product components (outputs) studied.

Based on the validation results from experts / experts and users (students, teachers and school principals), the evaluation of limited and expanded trials resulted in the conclusion that the EP_PISTdu evaluation model product was feasible to be used as a system to measure the Evaluation of the Integrated IPS Learning Program. This is indicated by the results of expert validation related to content validation which consists of validation of the instrument lattice, the suitability of the questionnaire and the program evaluation model guidelines are stated as appropriate. Similar to the validation by teachers, students, principals who stated that the evaluation model EP PISTdu was declared appropriate. Therefore it can be concluded that the EP_PISTdu evaluation model developed was declared feasible to be implemented as an evaluation result.

\section{The benefits and drawbacks of using Evaluation Model of EP_PISTdu}

The integrated social studies learning program evaluation model (EP PISTdu) has several advantages compared to other models, including (1) the integrated IPS learning program evaluation model (EP_PISTdu) is very comprehensive because the evaluation component is not only on the product, but includes input and the learning process itself. (2) this model is very practical, evaluation users are easy to understand and easy to implement in the field. (3) the integrated social studies learning program evaluation model (EP_PISTdu) is very economical because it does not involve many parties nor require a lot of money, effort and time. (4) the integrated social studies learning program evaluation model (EP_PISTdu) is very effective for use by school principals and social studies teachers without disturbing the teaching and learning process. (5) the integrated social studies learning program evaluation model (EP_PISTdu) strongly supports the implementation of the 2013 curriculum because the evaluation components are oriented to the 2013 curriculum.

The integrated social studies learning program evaluation model (EP_PISTdu) has several limitations, namely (1) the input component only consists of an assessment of teacher competence, student motivation and infrastructure. Meanwhile, other input components are not included in the input component. (2) the assessment of the process component, namely the implementation of the learning process in the classroom using only a questionnaire, not using direct observation in class. (3) the assessment of the product components, namely the cognitive domain learning outcomes take the documentation data of the USBN value, so that the evaluation results are limited to grade IX students of SMP only. (4) the integrated social studies learning program evaluation model (EP PISTdu) only evaluates three components, namely: the input component, the process and the product. Meanwhile, the context component is not included in the EP_PISTdu Model.

\section{Alternatives model of evaluation}

Although it has been considered to be one of the best evaluation models, there are some other alternatives that can be used to evaluate in social studies learning. (1) evaluation of the Provus Model (Discrepancy Model). This model, developed by Malcolm Provus, is an evaluation model that departs from the assumption that to determine the feasibility of a program, evaluators can compare what should be expected to happen (standard) and what actually happened (performance) so that discrepancies can be seen or not. By describing the gaps in each component of the program, corrective steps can be taken. (2) Stake Model Evaluation (Countenance Model). The model developed by Stake emphasizes the existence of two basic activities in evaluation, namely description and judgment and differentiates between three stages in educational programs, namely antecedent (context), transaction (process) and outcomes. (3) Evaluation of the Brinkerhoff Model. Evaluation Model Brinkerhoff has several evaluation designs, namely: (a) Fixed vs Emergent Evaluation Design. The fixed evaluation design is determined and planned in an integrated manner before implementation is undertaken. The design is developed based on program objectives accompanied by a set of questions that will be answered with information to be obtained from certain sources. (b) Formative vs Sumative Evaluation. Formative evaluation is used to obtain information that can help improve the program. Formative evaluation is carried out when program implementation is underway. Summative evaluation is carried out to assess the benefits of a program so that from the results of the evaluation it can be determined that a certain program will be continued or stopped. (c) Experimental and Quasi Experimental Design vs Nural / Unotrosive. In this case the research subjects were randomized, treatment was given and impact measurements were carried out. The aim of the research is to assess the benefits of a piloted program. If students or 
programs are randomly selected, generalizations are made to a somewhat broader population.

\section{Conclusions}

Integrated Social Sciences is one of the subjects taught at the junior high school level. This subject aims to improve understanding of students to be able to understand social phenomena. Therefore, it takes a very large effort to be able to increase understanding of students. In Indonesia, junior high school teaches integrated Social Sciences (IPS) as one of the subjects to teach social phenomena to the public. One of the targets in integrated social studies learning is to educate students to be able to recognize concepts related to the phenomena of society and their environment, so that they have the basic ability to be able to think critically and logically, have high curiosity, inquiry, and can solve problems and skills in social life. In addition, this integrated Social Sciences learning target also aims to make students be able to have commitment and awareness of humanity and social values. And finally, the Integrated Social Science aims to be able to have the ability to communicate, cooperate, and compete in a diverse society at the local, national and global levels.

In order to improve the quality of social studies achievement, it needs at least three kinds of evaluations in this subject matter, which are the evaluation of inputs, the evaluation of process, and the evaluation of product. Input evaluation is the raw material that is put into the transformation. In the world of schools, what is meant by raw materials are prospective students who are just about to enter school. Before entering a school level (institution), prospective students are assessed first for their ability; therefore one of the input evaluations carried out to students is a placement test. With this assessment, the results can be seen whether one day he will be able to follow the lessons and carry out the tasks that will be given to him.

Educational input is anything that must exist and is available because it is needed for a process to take place. Everything that is meant is in the form of resources, software and expectations as tools and guides for the progress of the process. This is very useful, because in the educational process, educational input is one of the most important things. However, educational inputs also require evaluation. In this case, input evaluation can be carried out by implementing midterm and final semester exams, so that social science education teachers can find out whether the material that has been taught to students can be understood or not.

The educational process is the changing of something into something else. Something that affects the progress of the process is called input, while something from the result of the process is called output. In education (school level) the process referred to is the decision-making process, the institutional management process, the program management process, the teaching and learning process, and the monitoring and evaluation process, provided that the teaching and learning process has a high level of importance compared to other processes.

The process will be said to be of high quality if the coordination and harmonization and integration of inputs (teachers, students, curriculum, money, equipment, etc.) are carried out harmoniously, so as to create a pleasant learning situation (enjoyable learning), able to encourage motivation and interest in learning, and really able to empower students. The word empower means that students do not just master the knowledge taught by the teacher, but the knowledge they get has also become the conscience of students, namely they are able to live, practice in everyday life, and most importantly these students are able to learn continuously or able to develop himself. In this case the process also requires evaluation to be able to know as a whole about how this knowledge can be processed.

Output is the finished material produced by the transformation. What is meant in this discussion is the student who graduated from the school concerned. To be able to determine whether a student has the right to pass or not, an assessment activity needs to be held, as a quality filtering tool. The output of education is school performance. Meanwhile, school performance itself is school achievement resulting from school processes or behavior. School performance can be measured by its quality, effectiveness, productivity, efficiency, innovation, quality of work life, and work morale. The output of education is the performance of the school. School performance is school achievement that results from school processes / behavior. School performance can be measured from its quality, effectiveness, productivity, efficiency, innovation, quality of work life and work morale.

\section{REFERENCES}

[1] Anderson, J. C., \& Gerbing, D. W. (1988). Structural Equation Modeling in Practice: A Review and Recommended Two-Step Approach. Psychological Bulletin, 1988. 103(3), 411-423.

[2] Aryani, D dan Rosinta, F. (2010). Pengaruh kualitas Layanan Terhadap Kepuasan Pelanggan Dalam Membentuk Loyalitas Pelanggan. Jurnal Ilmu Administrasi dan Organisasi.Vol.17. No.2.

[3] Bin, Xiong dan Yang Qing. (2008). Research on Evaluation Model of International Trade Bilingual education. Vol: 57-63.

[4] Fadia Nasser, Abu Alhija (2016). Teaching in higher education: Good Teaching through students' lens. Journal International of Studies in Education Evaluation

[5] Ferdinand, Augusty. Structural Equation Modeling dalam Penelitian Manajemen, Edisi Ketiga, (Semarang.: Fakultas Ekonomi UNDIP. 2006) 
[6] Ghozali, Imam. (2009). Aplikasi Analisis Multivariate dengan Program SPSS. Semarang: UNDIP

[7] George G. Bear (2017). Rewards, praise, and punitive consequences: Relations With intrinsic and extrinsic motivation. Journal of Teaching and Teacher Education.

[8] Gwartney James and Schug Mark C. (2011). What Every High School Student and Teacher Needs to Know About Economics. New York: Routledge.

[9] Hair, J. F., Black, W. C., Babin, B. J., Anderson, R. E., \& Tatham, R. L. (2010). Multivariate data analysis (6th ed.). Upper Saddle River, NJ: Pearson/Prentice Hall.

[10] Komarudin, Alkhudri, A. T., Ubedilah, Syaifudin, S., \& Casmana, A. R. (2019). The Nationality Education Model: The Implementation of a "Score-A" Training Model for Youth across Different Cultures in Indonesia. Journal of Social Studies Education Research, 10(2), 308-322. Retrieved from http://files.eric.ed.gov/fulltext/EJ1220766.p df

[11] Latan, Hengky. (2013). Model Persamaan Struktural Teori dan Implementasi. Bandung: CV. Alfabeta.

[12] Malderez, Angi \& Wedell, Martin. 2007. Teaching Teachers; Processes and Practices. New York: McGraw-Hill

[13] Maximiliane (2017). The impact of science motivation on cognitive achievement within a 3-lesson unit about renewable energies. Journal International of Studies in Education Evaluation

[14] Neyati, Arab, Freshteh Farzianpour dan Majdabadi (2016). Evaluation of selected faculties at Tehran University of Medical Sciences using CIPP model in students and graduates point of view, International Journal of Evaluation and Program Planning

[15] Sarkadi, \& Casmana, A. R. (2020). The Application of Empathetic Learning in Facing the Covid-19 Pandemic as the Responsibility of Good Citizens. International Journal of Psychosocial Rehabilitation, 24(9), 1475-7192.

[16] Sarkadi, Casmana, A. R., \& Rahmawati, Y. (2020). Improved Learning Design for Pre-Service Teacher in a Character Education Course. Universal Journal of Educational Research, 8(1), 212-224. doi:10.13189/ujer.20 20.080126

[17] Singgih Santoso. 2012. Structural Equation Modeling (SEM)
Konsep dan Aplikasi dengan AMOS 18. Jakarta: Penerbit PT Elex Media Komputindo.

[18] Schumacker, R.E. \& R.G Lomax. A Beginner's Guide to Structural Equation Modeling. Second Edition. Edition. (New Jersey: Jersey: Lawrence Erlbaum Associates, Inc. Pub. 2004)

[19] Schug Mark C. And Wood William C., (2011). Teaching Economics in Troubled Times, Theory and Practice for Secondary Social Studies. New York: L Routledge.

[20] Segall Marshall H. (et allo, 1990. Human behavior in global perspective. Brorton: Allyn and Bacon.

[21] Suhadi, Syafrudin, I., \& Casmana, A. R. (2020). The Political Culture of the Cigugur Society, Indonesia. International Journal of Psychosocial Rehabilitation, 24(9), 1168-1175.

[22] Sumadi, T., \& Casmana, A. R. (2020). The Importance of Social Competences Transformation towards Early Age Children in Jakarta. Universal Journal of Educational Research, 8(5), 1991-1996. doi:10.13189/ujer.2020.080536

[23] Zakaria Wahab, Muchsin S. Shihab, Agustina Hanafi, and Hera Febria M (2018); The Influence of Online Shopping Motivation and Product Browsing toward Impulsive Buying of Fashion Products on a Social Commerce; International Journal of Scientific and Research Publications (IJSRP) 8(7) (ISSN: 2250-3153)

[24] Zhang, Guili Et Al. (2011). Using the Context, Input, Process, and Product evaluation Model (CIPP) as a Comprehensive Framework to Guide the Planning, Implementation, and Assessment of Service-Learning Programs. Journal of Higher education Outreach and Engagement, 15 (4): 57:83

[25] Zid, M., Alkhudri, A. T., Casmana, A. R., Marini, A., \& Wahyudi, A. (2020). Ex Migrant Workers of International Women and Social Entrepreneurship: Study at Kenanga Village in Indramayu Regency in West Java Province in Indonesia. International Journal of Advanced Science and Technology, 29(06), 1855-1861.

[26] Zid, M., Casmana, A. R., \& Hijrawadi, S. N. (2020). The Development of International Education towards Migration Abroad by Indonesian Women. Universal Journal of Educational Research, 8(5), 1953-1963. DOI: 10.13189/ujer.2020.080532 